\title{
In situ measurement of respiratory metabolism and nitrogen fluxes at the interface of oyster beds
}

\author{
Guy Boucher, Renata Boucher-Rodoni
}

UA699 CNRS, Laboratoire de Biologie des Invertébrés Marins et de Malacologie, Muséum National d'Histoire Naturelle, 55 rue de Buffon, F-75231 Paris, France

\begin{abstract}
Nitrogen and oxygen fluxes were measured in situ during monthly dark enclosure experiments on oyster beds. The incubations were performed on undisturbed sediment with its endofauna, on 10 oysters Crassostrea gigas isolated from the substratum, and on 10 oysters associated with the sediment, to assess the impact of oyster farming on the environment. Ammonia was released by the sediment following a seasonal pattern, displaying low winter $\left(51 \mu \mathrm{mol} \mathrm{m}^{-2} \mathrm{~h}^{-1}\right)$ and high spring (237

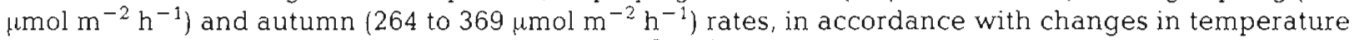
and oxygen consumption (22 and $163 \mathrm{mg} \mathrm{O}_{2} \mathrm{~m}^{-2} \mathrm{~h}^{-1}$ in winter and spring respectively). Nitrate was mainly absorbed into the sediment, up to $120 \mu \mathrm{mol} \mathrm{m} \mathrm{m}^{-2} \mathrm{~h}^{-1}$ in winter, when the water column concentration was high. Organic nitrogen (urea and primary amines) contributed significantly to increase the rate of nitrogen release during summer and autumn. In spite of a summer deficit of ammonia exchange and of inorganic and organic nitrogen accumulation into the sediment, the coupling between oxygen uptake and nitrogen release was still significant. A similar seasonal pattern governs the metabolic rates of oysters; ammonia excretion increased in spring $\left(3.21 \mu \mathrm{mol} \mathrm{g} \mathrm{g}^{-1} \mathrm{~h}^{-1}\right)$ and autumn (2.5 to $\left.6.7 \mu \mathrm{mol} \mathrm{g} \mathrm{g}^{-1} \mathrm{~h}^{-1}\right)$, compared to low winter values $\left(0.28 \mu \mathrm{mol} \mathrm{g} \mathrm{g}^{-1} \mathrm{~h}^{-1}\right)$, in accordance with changes in temperature and oxygen consumption $\left(0.14\right.$ and $1.3 \mathrm{mg} \mathrm{O}_{2} \mathrm{~g}^{-1} \mathrm{~h}^{-1}$ in winter and summer respectively). Some nitrate production was observed, suggesting occasional nitrification. Primary amine exchanges were rather erratic, whereas urea seems to play an important role seasonally as a nitrogenous end-product, in relation to a lower condition index at the end of the winter A simple budget of sedment-water exchanges, calculated on a $\mathrm{m}^{-2}$ basis (e. $\mathrm{g} .2 \mathrm{~kg}$ oysters $\mathrm{m}^{-2}$ ), indicates that over the year the oysters' contribution to the fluxes averages 37 and $40 \%$ for ammonia and urea release respectively, and $26 \%$ for oxygen uptake. However, the actual contribution of oysters to the exchanges at the water-sediment interface rarely fits the expected values from potential estimates. Oxygen consumption, ammonia release and nitrate absorption of the association of oysters with sediment are mainly depressed, except during winter and early spring when respiration is stimulated
\end{abstract}

\section{INTRODUCTION}

In coastal waters, a significant proportion of nutrients for primary production is provided by remineralization of particulate matter within bottom communities (Zeitzschel 1980, Nixon 1981). Input of organic matter from the water column influences benthic metabolism and nutrient release (Hargrave 1980, Bulleid 1984, Kelly \& Nixon 1984). The fluxes at the interface also depend on rates of detritus decomposition and of nutrient release from interstitial water to the overlying water by diffusion or biological activity.

Benthic organisms can make substantial contributions to total benthic oxygen uptake and nutrient regeneration by their own metabolic processes (Pamatmat 1968, Smith 1973, Nixon et al. 1980). Dense assemblages of filter-feeding organisms, such as oys- ters, act as biological filters removing material from the water and releasing dissolved end-products. Their feces and pseudofeces production modify the quantity and quality of particulate matter input to the sediment (Galtsoff 1964, Dame et al. 1979, 1984)

In a previous paper (Boucher \& Boucher-Rodoni 1985), the fluctuations of nutrient concentrations in the water column above oyster beds in the Bay of Morlaix (North Brittany, France) were evaluated during tidal cycles. Ammonia concentration fluctuations appeared to be related to the presence of dense assemblages of macrofauna, whereas nitrate, silicate and phosphate seemed to be influenced mainly by the tidal flows. In the present article, we report the results of in situ enclosure incubations designed to evaluate experimentally the temporal variations of oxygen uptake and nutrient exchange at the interface of oyster beds by 
undisturbed sediment and by oysters Crassostrea gigas. The purpose of these investigation was to estimate the potential and actual contribution of a high density of epibenthic filter-feeding organisms, such as oysters, to oxygen consumption and to the system flux of nitrogen (ammonia, nitrate, primary amines, urea) at the interface

\section{MATERIAL AND METHODS}

Study site. The oyster bed chosen for the study is located in the Bay of Pempoul (Bay of Morlaix, North Brittany, France: $\left.48^{\circ} 40^{\prime} 50^{\prime \prime} \mathrm{N}, 3^{\circ} 56^{\prime} 30^{\prime \prime} \mathrm{W}\right), 3.5 \mathrm{~m}$ above the lowest chart level. The local tidal height is ca $9 \mathrm{~m}$, which means a few hours emersion of the bed only at spring low tides. Tidal currents at spring tides can be as high as $2 \mathrm{~m} \mathrm{~s}^{-1}$, but are weak at neap tides. Salinity ranges from 33 to $35 \%$.

Granulometry and benthos composition were analysed previously (Boucher \& Boucher-Rodoni 1984). The sediment consists of fine sand with an admixture of broken oyster shells. Its granulometry remains stable throughout the year, with a mean grain size of $201 \pm$ $1 \mu \mathrm{m}$, and a low silt content of $2.6 \pm 0.1 \%$. Interstitial water content was constant ( 19 to $20 \%$ of wet weight). Macrophyte proliferation, mainly of Ulva species, begins in May and lasts until October. Seasonal changes of meiofauna exhibit a clear spring and summer bloom, contributed to mainly by nematodes (5176 \pm 1098 ind. $10 \mathrm{~cm}^{-2}$ in June compared to $1377 \pm 381$ ind. $10 \mathrm{~cm}^{-2}$ in December). The densities of harpacticoid copepods are lower, ranging from $20 \pm 4$ (winter) to $251 \pm 82$ ind. $10 \mathrm{~cm}^{-2}$ (autumn). Macrofauna composition and biomass are stable over the year (around $45 \mathrm{~g}$ dry wt $\mathrm{m}^{-2}$ ). The dominant species are the polychaetes Amphitrite johnstoni $153 \%$ of total biomass), Lanice conchylega and Sabella pavonina.

Adult oysters Crassostrea gigas were transplanted onto these beds in January (mean total body weight 40 g) and harvested in December $(80 \mathrm{~g}$ total body weight, i. e. commercial size). Due to storm losses and predation, the total biomass harvested (20 tonne ha ${ }^{-1}$ ) was the same as that introduced, in spite of individuals' growth. Liberation of gametes does not occur in North Brittany since the water temperature is always below $18^{\circ} \mathrm{C}$.

Enclosure design. Nutrient and oxygen fluxes at the sediment-water interface were measured in the water trapped in enclosures. During the spring low tide preceding experimentation, at emersion, the bases of three $50 \mathrm{~cm}$ diameter PVC tubes $\left(0.2 \mathrm{~m}^{2}\right)$ were pushed into the oyster-free sediment, ensuring that a minimum of $10 \mathrm{~cm}$ vertically was inserted in the substrate. Two chambers were placed on undisturbed sediment with its endofauna and epifauna. One of them was left without oysters, and in the other 10 oysters were added, so that a natural environment could develop between the oysters and the sediment. The experimental individuals were previously brushed to minimize fouling contribution to the fluxes. In the third chamber, the substrate was isolated from the overlying water by placing a watertight PVC plate at the interface level. During the next neap tide, the experiments were carried out by SCUBA diving. Just before starting the incubation, 10 other experimental oysters were gently placed on the plate of the third chamber for excretion evaluation. Then, the enclosures were closed with clear acrylic hemispheres to trap a known volume of bottom water, varying from 40 to $50 \mathrm{l}$ according to the depth of core insertion into the substrate. The enclosures were darkened with black polyethylene plastic foil. Gusher galley pumps (Whale MKIII), connected to a $12 \mathrm{~V}$ battery on a surface raft, maintained a $12 \mathrm{I} \mathrm{min}^{-1}$ closed-circuit flow rate through each enclosure, allowing good mixing without noticeable particulate resuspension.

Experiments were performed at monthly intervals (September 1984 to December 1985), always at neap tide, while the site was covered by 1 to $4 \mathrm{~m}$ of water. The incubations were started in the morning 10:00 to 12:00 h) and lasted $4 \mathrm{~h}$, a duration allowing changes of concentration in the trapped water without critical oxygen depletion and ammonia accumulation. Samples for water analyses were withdrawn each hour by SCUBA diving, from $T_{0}$ to $T_{5}$, with a $1 \mathrm{l}$ syringe. Outside water was admitted through a port during sampling to avoid interstitial water release from the sediment. Oxygen and ammonia samples were immediately fixed on the raft for later analysis. A volume of $250 \mathrm{ml}$ was filtered on board with a Millipore pump on Whatman GF/A filters, and the filtrate was kept on crushed ice before being deep-frozen in the laboratory for later analysis of other nutrients. Oxygen was measured by the Winkler method, ammonium by the indo-phenol blue method (Solorzano 1969), nitrate + nitrite by the Technicon Industrial method (Treguer \& LeCorre 1975), amino acids by the fluorescamine method (Udenfriend et al. 1972) and urea by the method of Aminot \& Kerouel (1982) in a Technicon autoanalyzer. Dissolved organic nitrogen (DON) was assumed to be the sum of primary amines and urea.

Biodeposition rate of oysters ( $\mathrm{mg}\left[\mathrm{g}\right.$ dry $\mathrm{wt}^{-1} \mathrm{~d}^{-1}$ ) was estimated over $24 \mathrm{~h}$ in the vicinity of the enclosures, using feces collectors similar to those described by Sornin (1981). Feces and pseudofeces production by 3 oysters lying in a funnel was estimated on 5 replicates, after correcting for natural sedimentation in 5 funnels with empty shells.

The biomass of the 10 experimental oysters $(60$ to $80 \mathrm{~g}$ total fresh weight per individual) in the enclosures 
was expressed as total wet weight (including shells) for the areal evaluation of their contribution to the fluxes, and as dry weight of the meat $\left(72 \mathrm{~h}\right.$ at $60^{\circ} \mathrm{C}$ ) for physiological rates. No normalization of the measured metabolic rates was performed for temperature and weight of oysters, since our purpose was to estimate their potential and actual contribution to interface fluxes at different periods of the year and to compare their rates with that of raw sediments. The mean biomass of oysters at the study site was evaluated as $2 \mathrm{~kg}$ $\mathrm{m}^{-2}$ (total fresh weight including shell), though it could reach $8 \mathrm{~kg} \mathrm{~m}^{-2}$ elsewhere.

Dark-bottle controls indicated that planktonic contribution to the fluxes was low compared to benthic fluxes. For each enclosure, the rate of change of concentration ( $m g \mathrm{O}_{2} \mathrm{l}^{-1} \mathrm{~h}^{-1}$, or $\mu \mathrm{mol} \mathrm{N} \mathrm{l}^{-1} \mathrm{~h}^{-1}$ ) was calculated by linear regression of the 4 to 6 measures, corrected for water volume calculated in the enclosure and for bottom surface or oyster weight. Dilution compensating for water withdrawal was assumed to be negligible ( 7 to $9 \%$ according to the experiment).

\section{RESULTS}

\section{Water column}

Initial concentrations in the 15 series of enclosure experiments were used to follow the temporal fluctuations of oxygen and nitrogen compounds in the water

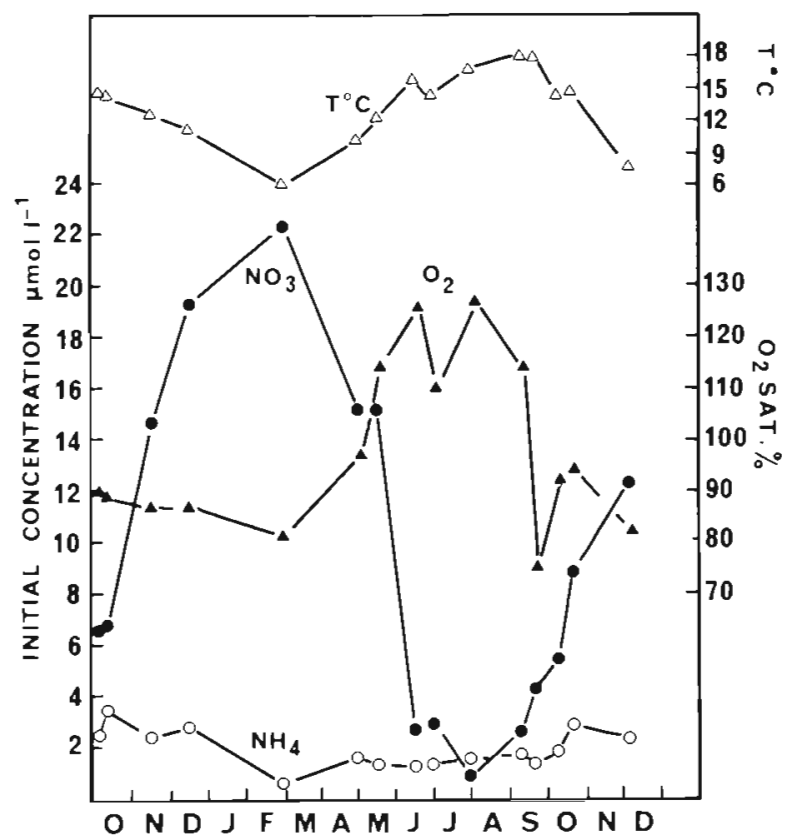

Fig. 1. Seasonal fluctuations of temperature $\left({ }^{\circ} \mathrm{C}\right)$, oxygen saturation (\%), and nitrate and ammonia initial concentrations ( $\mu \mathrm{mol} \mathrm{l}^{-1}$ ) in the water trapped in the enclosures column above oyster beds (Fig. 1). Ammonia concentration was low from February to September 0.5 to $\left.1.7 \mu \mathrm{mol} \mathrm{l}^{-1}\right)$ and increased slightly in late autumn $(1.8$ to $3.4 \mu \mathrm{mol} \mathrm{l}^{-1}$ ). Nitrate concentrations were highest during the winter, from November to May (15 to 22 umol $1^{-1}$ ), mostly due to high exogenous input from river runoff (Wafar 1981). The concentrations decreased to a low level in summer, from June to September $\left(0.8\right.$ to $\left.2.9 \mu \mathrm{mol} \mathrm{l} \mathrm{l}^{-1}\right)$. Percentage saturation of oxygen varied from 75 to $97 \%$ from September to April, but values increased up to $127 \%$ in the summer experiments

\section{Sediment}

Oxygen was consumed in the sediment-only enclosures (Fig. 2a) at higher rates during the summer (up to $163 \mathrm{mg} \mathrm{m}^{-2} \mathrm{~h}^{-1}$ ) than during the winter (22 $\mathrm{mg}$ $\mathrm{m}^{-2} \mathrm{~h}^{-1}$ ). Ammonia, primary amines and urea fluxes at the water-sediment interface were positive, that is they were released from the sediment to the water column, whereas nitrates $\left(\mathrm{NO}_{3}+\mathrm{NO}_{2}\right)$ were mainly absorbed (Fig. 2b).

To test the replicability of the results, a series of consecutive experiments was performed at different periods of the year. The base of the enclosures was left undisturbed overnight after an incubation and a new experiment was performed the following day. Oxygen and ammonia fluxes underwent slight variations, but nitrate showed major changes. An inversion of nitrate fluxes suggests a stimulation of nitrification without immediate denitrification, thus enhancing the nitrate gradient (Table 1). The sensitivity of the response of nitrate flux to the changes induced at the interface by $4 \mathrm{~h}$ confinement the previous day led us to consider only the first day experiment of each series as representative of monthly fluctuations.

Ammonia was usually the main nitrogen compound released to the water column, its weighted average over the year representing $52 \%$ of nitrogen diffusion. Rates were higher from spring (121 to $237 \mu \mathrm{mol} \mathrm{\textrm {m } ^ { - 2 }}$ $\mathrm{h}^{-1}$ ) to autumn ( 147 to $369 \mu \mathrm{mol} \mathrm{m}^{-2} \mathrm{~h}^{-1}$ ) than in winter (51 to $93 \mu \mathrm{mol} \mathrm{m} \mathrm{m}^{-2} \mathrm{~h}^{-1}$ ) (Fig. $2 \mathrm{~b}$ ). High absorption of nitrate into the sediment occurred during winter (up to $-120 \mu \mathrm{mol} \mathrm{m}{ }^{-2} \mathrm{~h}^{-1}$ ), when the water concentration was highest and temperature lowest. Dissolved inorganic nitrogen fluxes (DIN, e.g. nitrate + ammonia) were always positive, except in February, when nitrate absorption exceeded ammonia release. Primary amines were released in most of the experiments, at higher rates in autumn (64 to $184 \mu \mathrm{mol} \mathrm{m} \mathrm{m}^{-2} \mathrm{~h}^{-1}$ ), than from December to June ( 7 to $65 \mu \mathrm{mol} \mathrm{m} \mathrm{m}^{-2} \mathrm{~h}^{-1}$ ). An increased urea release (up to $49 \%$ of total nitrogen flux) was measured from spring to autumn (56 to $275 \mu \mathrm{mol} \mathrm{m} \mathrm{m}^{-2}$ 

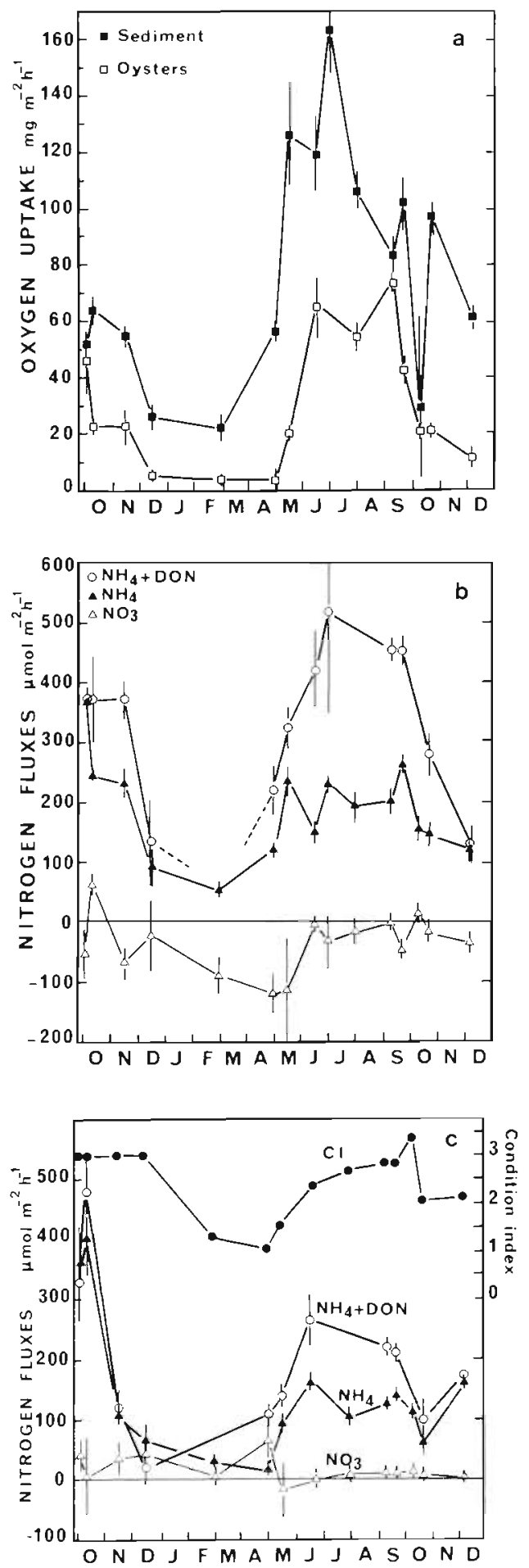

Fig. 2. Seasonal fluctuations of fluxes, measured monthly in dark incubations. (a) Oxygen consumption $\mathrm{m}^{-2}$, for sediment alone and for $2 \mathrm{~kg} \mathrm{~m}^{-2}$ oysters ( $\mathrm{mg} \mathrm{m} \mathrm{m}^{-2} \mathrm{~h}^{-1}$ ). (b) Nitrogen fluxes through the sediment interface: ammonia and dissolved organic nitrogen $\left(\mathrm{NH}_{4}+\mathrm{DON}\right)$, ammonia alone, nitrate + nitrite $\left(\mu \mathrm{mol} \mathrm{m}^{-2} \mathrm{~h}^{-1}\right)$. (c) Condition index of oysters [(meat dry wt/total fresh wt) $\times 100]$, and nitrogen fluxes by $2 \mathrm{~kg} \mathrm{~m}^{-2}$ oysters: ammonia + DON, ammonia. nitrate + nitrite ( $\mu \mathrm{mol}$

$$
\mathrm{m}^{-2} \mathrm{~h}^{-1} \text { ) }
$$

Table 1. Oxygen and nitrogen fluxes in a series of consecutive experiments on the same area at different periods of the year Inversion of nitrate fluxes was observed between Day 1 and Day 2 in all experiments

\begin{tabular}{|lcrrrr|}
\hline Month Day & $\begin{array}{c}\text { Oxygen } \\
\left(\mathrm{mg} \mathrm{m}^{-2}\right. \\
\left.\mathrm{h}^{-1}\right)\end{array}$ & $\begin{array}{c}\text { Ammonia } \\
\left(\mu \mathrm{mol} \mathrm{m} \mathrm{m}^{-2}\right. \\
\left.\mathrm{h}^{-1}\right)\end{array}$ & $\begin{array}{c}\text { Nitrate } \\
(\mu \mathrm{mol}) \\
\left.\mathrm{m}^{-2} \mathrm{~h}^{-1}\right)\end{array}$ & $\begin{array}{c}\mathrm{DIN} \\
\left(\mu \mathrm{mol} \mathrm{m} \mathrm{m}^{-2}\right. \\
\left.\mathrm{h}^{-1}\right)\end{array}$ \\
\hline Nov & 1 & -54.9 & 232 & -67 & 165 \\
& 2 & -43.0 & 166 & +114 & 280 \\
Jun & 1 & -119.1 & 149 & -3 & 146 \\
& 2 & -70.2 & 156 & +90 & 246 \\
Sep & 1 & -101.9 & 264 & -47 & 217 \\
& 2 & -68.8 & 134 & +28 & 162 \\
Dec & 1 & -31.1 & 119 & -34 & 85 \\
& 2 & -46.2 & 100 & 0 & 100 \\
\hline
\end{tabular}

$\left.\mathrm{h}^{-1}\right)$, and hence, total dissolved inorganic and organic nitrogen $\left(\mathrm{NH}_{4}+\right.$ DON, e. g. ammonia + urea + primary amines) release displayed a marked increase in summer (Fig. 2b).

Spearman rank correlation coefficients were calculated to assess the significance (at $p<0.05$ and at $\because p<0.01$, for $n=15$ ) of the relationships between temperature, initial concentrations and fluxes at the interface. All exchange processes were temperature dependent (at $p<0.05$ ). Ammonia release showed no relation to any other parameter than temperature, suggesting seasonal fluctuations, perhaps related to the temperature-dependent ammonia production of bacteria and infauna. Initial concentrations of most parameters are not correlated with temperature, except nitrate $\left(r=0.86^{*}\right)$, which showed a marked seasonal cycle. Again, nitrate concentration is the main parameter, besides temperature, influencing the nitrate flux at the interface $\left(r=0.61^{\circ}\right)$. Urea release is enhanced with increasing oxygen consumption $\left(r=0.79{ }^{\circ}\right)$. The metabolic pathways of ammonia and urea production might explain the complex relationships between urea release and ammonia concentration $\left(r=-0.62^{\circ}\right)$, and oxygen consumption. A seasonal production of urea in sediments could be associated with high respiratory rates, since catabolic end-products (e. g. ammonia) are rapidly fixed to carbonate and exchanged as urea, minimizing the apparent ammonia production. The relationship between oxygen uptake and ammonia release is however significant when fitted according to a multiplicative model (Fig. 3a). The stimulation of ammonia diffusion in summer is not proportional to the oxygen consumption increase. However, if dissolved organic nitrogen (e.g. mainly urea) is added to ammonia, the summer deficit of ammonia release is reduced. 

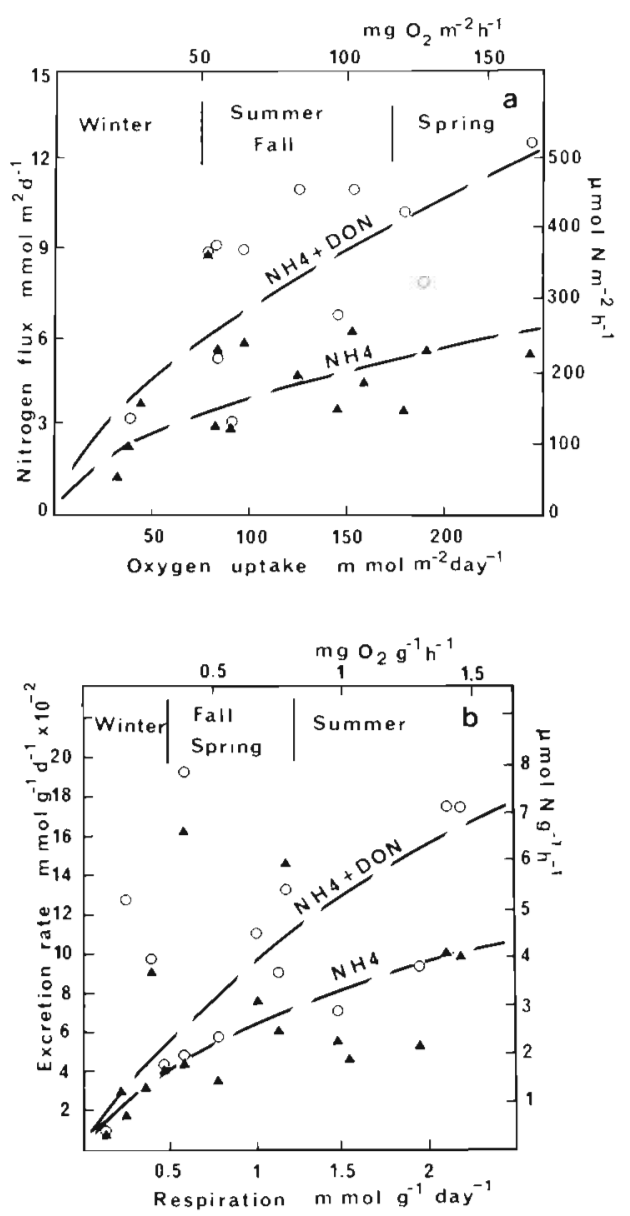

Fig. 3. Relation between oxygen consumption and nitrogen fluxes. (a) Fluxes at the sediment interface $\left(\mathrm{mmol} \mathrm{m}^{-2} \mathrm{~d}^{-1}\right.$ ) fitted according to a log-log model, $Y=-0.82 X^{0.45}$ for $\mathrm{NH}_{4}(\mathbf{\Delta})$ $(p<0.025 ; \quad r=0.59 ; n=15)$, and $Y=-0.91 X^{0.62}$ for $\mathrm{NH}_{4}+\mathrm{DON}(0)(p<0.025 ; r=0.68 ; n=12)$. Additional scales: umol $\mathrm{m}^{-2} \mathrm{~h}^{-1}$ for nitrogen and $\mathrm{mg} \mathrm{m}^{-2} \mathrm{~h}^{-1}$ for oxygen. (b) Exchange rates of oysters ( $\mathrm{mmol} \mathrm{g} \mathrm{g}^{-1} \mathrm{~d}^{-1}$ ), fitted according to a $\log$-log model. For ammonia alone (4), the regression is significant at the $p<0.002$ level $\left(Y=-2.87 X^{(1)}\right) ; r=0.68 ; n=$ 15), and the $p<0.001$ level when dissolved organic nitrogen is added to ammonia $(Y)\left(Y=-2.34 X^{0.63} ; r=0.65 ; n=12\right)$. Additional scales: $\mu \mathrm{mol} \mathrm{g} \mathrm{g}^{-1} \mathrm{~h}^{-1}$ for nitrogen and $\mathrm{mg} \mathrm{g}^{-1} \mathrm{~h}^{-1}$ for oxygen

\section{Oysters}

In situ dark incubations with 10 oysters revealed seasonal variations of the metabolic rates (Fig. 2a). Respiration was highest from late spring to late summer (0.67 to $\left.1.30 \mathrm{mg} \mathrm{g}^{-1} \mathrm{~h}^{-1}\right)$, and decreased during winter $\left(0.08\right.$ to $\left.0.26 \mathrm{mg} \mathrm{g}^{-1} \mathrm{~h}^{-1}\right)$. Ammonia was the main endproduct of nitrogen metabolism (mean weighted average: $54.5 \%$ ), and was excreted at higher rates during spring (2.29 to $3.13 \mu \mathrm{mol} \mathrm{g}{ }^{-1} \mathrm{~h}^{-1}$ ) and autumn (1.65 to $\left.6.75 \mu \mathrm{mol} \mathrm{g}{ }^{-1} \mathrm{~h}^{-1}\right)$ than winter $\left(0.28\right.$ to $1.21 \mu \mathrm{mol} \mathrm{g}{ }^{-1}$ $\left.\mathrm{h}^{-1}\right)$. Amino acid exchanges were erratic $(0.0$ to 1.1 $\left.\mu \mathrm{mol} \mathrm{g}^{-1} \mathrm{~h}^{-1}\right)$, and their seasonal fluctuations were not significant. Urea production was greater during spring and summer $\left(0.8\right.$ to $\left.4.2 \mu \mathrm{mol} \mathrm{g}^{-1} \mathrm{~h}^{-1}\right)$ than in autumn and winter $\left(0.05\right.$ to $\left.0.63 \mu \mathrm{mol} \mathrm{g}^{-1} \mathrm{~h}^{-1}\right)$. Nitrate fluxes were rather low but suggest that occasional enhanced nitrification can occur, particularly during winter (up to $0.72 \mu \mathrm{mol} \mathrm{g}{ }^{-1} \mathrm{~h}^{-1}$ ).

Spearman correlation coefficients were calculated between temperature, oyster weight and metabolic rates to detect the main connections between parameters $(n=15)$. The significant relationships between metabolic rates and total fresh weight variations are a matter of chance since the experiments were performed on oysters sampled on the basis of 60 to $80 \mathrm{~g}$ total fresh weight (with shells) per individual. However, the dry weight and the condition index [ (meat dry wt/total fresh wt) $\times 100$ ] varied significantly over the year (Fig. 2C), the winter low feeding rate and gonad resorption being responsible for oysters' flesh weight loss. Increased urea excretion coincided with late winter and spring low dry weight and low condition index ( $r=0.766^{\circ}$ and $-0.73 \cdots$ respectively). Oxygen consumption increased seasonally with increasing temperature $\left(r=0.87^{\circ}\right.$ ") . A negative relation between ammonia and nitrate fluxes $\left(r=0.60^{\circ}\right)$ suggests that nitrification processes might be stimulated in the presence of oysters, thus decreasing the apparent ammonia release.

Oxygen consumption is related to ammonia excretion $(r=0.64 \cdots)$, a relation that can be illustrated by a plot according to a multiplicative model (Fig. 3b). The proportion of DON (mainly urea) contribution to total nitrogen excretion rises with increasing oxygen consumption.

The metabolic rates measured on 10 adult oysters were recalculated to a mean biomass of $2 \mathrm{~kg} \mathrm{~m}^{-2}$ (Fig. $2 \mathrm{a}, \mathrm{c})$. When compared to simultaneous sediment incubation experiments, oxygen consumption and ammonia and DON release of this oyster biomass followed the same seasonal pattern and never exceeded sediment rates, except in some autumn experiments.

Some biodeposition experiments were performed simultaneously with enclosure incubations, from May to December. Feces and pseudofeces production ranged from 66 to $246 \mathrm{mg}$ (g dry $\left.\mathrm{wt}^{-1}\right)^{-1} \mathrm{~d}^{-1}$ with a mean value of $123 \mathrm{mg}$. The production rate was highest in May and October, and decreased during summer, probably in relation with enhanced feeding rates during the increased spring and autumn primary production. This seasonal pattern can however vary according to high winter turbidity or to the intensity of summer productivity, as reported from other ecosystems (Bernard 1974, Sornin et al. 1983). 


\section{Association of oysters and sediment}

The oxygen consumption rates and nitrogen fluxes of 10 oysters placed on $0.2 \mathrm{~m}^{-2}$ undisturbed sediment followed the same annual trend as sediment and oysters alone. The respiration of the association was of the same order of magnitude as the sum of separate metabolism during autumn and winter, but decreased to lower values during spring and autumn (Fig. 4a). Ammonia fluxes from the association of oysters and sediment seldomly reached the values expected by adding the rates of both compartments (Fig. 4b). Such is also the case for urea and primary amines. On the contrary, decreased nitrate uptake and sometimes even nitrate release are observed when oysters are associated to the sediment (Fig. 4c).
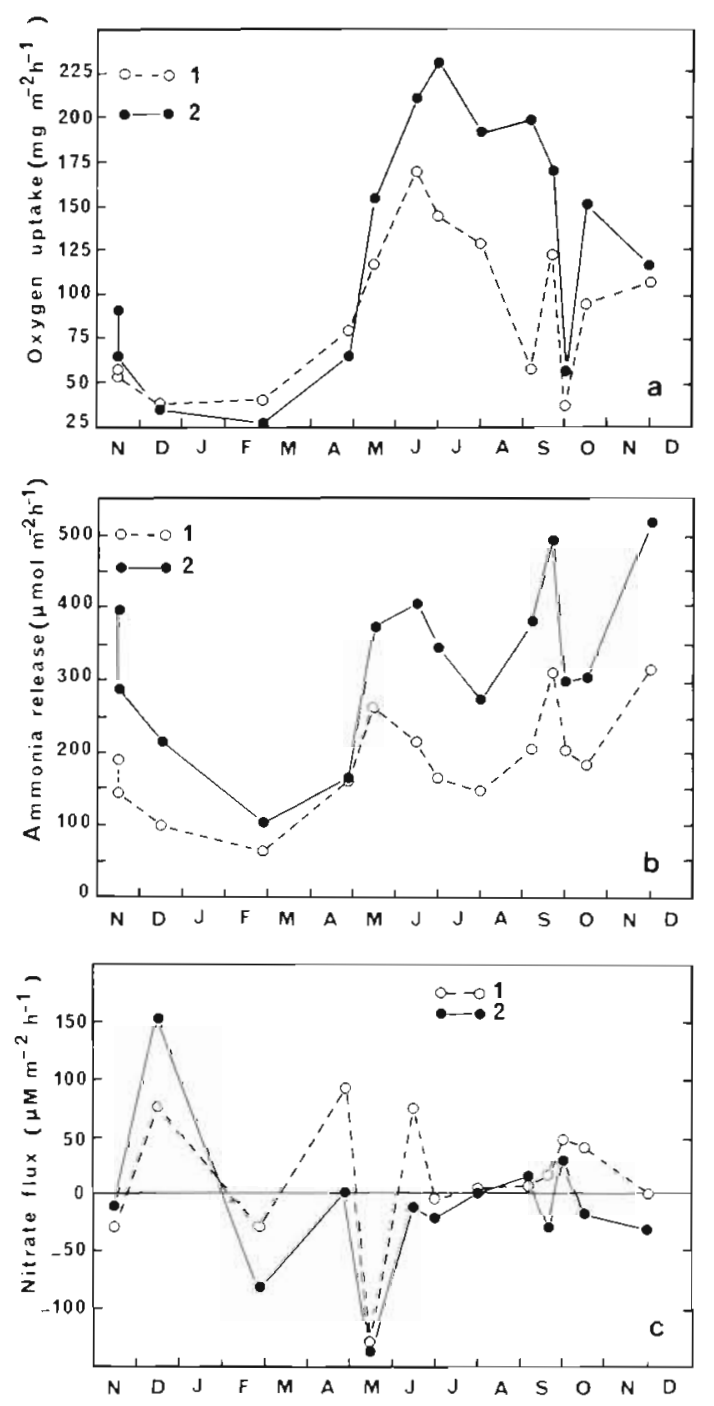

Fig. 4. Seasonal fluctuations of actual $(1 ;$ association of 50 oysters and $1 \mathrm{~m}^{2}$ sediment) and potential (2; sediment alone + oysters alone) fluxes in dark enclosures. (a) Oxygen uptake (mg m $\mathrm{m}^{-2} \mathrm{~h}^{-1}$ ). (b) Ammonia release (umol $\mathrm{m}^{-2} \mathrm{~h}^{-1}$ ). (c) Nitrate flux ( $\left.\mathrm{mol} \mathrm{m} \mathrm{m}^{-2} \mathrm{~h}^{-1}\right)$

\section{DISCUSSION}

On an annual basis, oxygen and nitrate are mainly taken up by the sediment of oyster beds whereas ammonia, urea and primary amines are released to the water column. Oysters metabolic activities influence the intensity of these exchange rates, by their own respiration and excretion. Soluble end-products are released to the surrounding water, and biodeposits modify the particulate input into the sediment.

Our results are in agreement with those of most previous enclosure experiments performed on coastal sediments. Ammonia release and particularly oxygen consumption at the interface are however in the upper range when compared to results obtained by Nixon (1981) and Fisher et al. (1982), in spite of a rather coarse grain size. At the sediment-water interface, the fluxes are probably governed by a set of complex seasonal factors, such as temperature, water column concentrations and concentration gradients in the sediment resulting from particulate matter input or shift in microbial metabolism and biological activity. It is generally accepted that biological rates are related to temperature, showing a 2-to 4 -fold increase for $10 \mathrm{C}^{\circ}$ temperature rise (Nixon et al. 1976, Klump \& Martens 1983). Our data confirm this trend for oxygen and ammonia, and show that fluxes of dissolved organic nitrogen compounds (mainly urea) also follow a similar pattern. Ammonia and nitrate storage in the sediment of the same oyster bed during summer (Lerat et al. 1985) facilitates an increased ammonia release, but nitrate uptake still prevails, although at lower rates, in relation with low concentration of nitrate, in the water column. Nitrate uptake is known to be governed by the concentration in the water column (Nedwell 1982, Kristensen 1984), and is at a maximum during winter when nitrate supply is abundant, and pore water concentration low. Thus, denitrification is fuelled by the rich water column input during winter, whereas during summer enhanced nitrification in the aerobic zone of the sediment is the main source of nitrates (Brezonik 1977. Boynton et al. 1980). Summer increase in biological activity of endofauna (mainly Amphitrite johnstoni) stimulates the exchange rates at the interface and the metabolism of nitrifying bacteria controlled by the depth of penetration of oxygen into the substrate (Aller 1978, Henriksen et al. 1981, 1983). Dense assemblages of Lamellibranches might enhance the processes (Kaspar et al. 1985), because of their effect on infaunal composition (Tenore et al. 1982) and because of high potential nitrification of their feces (Henriksen et al. 1983). The summer moderate biodeposition of oysters (mainly feces) could stimulate more nitrification than the increased winter and spring production (mainly pseudofeces). 
A stoichiometric coupling between organic matter consumption (as measured by oxygen uptake) and inorganic nitrogen release was thought improbable by Kemp \& Boynton (1979) and by Fisher et al. (1982), whereas Boynton et al. (1980) and Nixon (1981) showed that ammonium release is related to oxygen consumption in different coastal marine systems and over the year. In the oyster bed sediments, the increased oxygen uptake during summer is not totally balanced by a corresponding increase of ammonia release. This apparent nitrogen deficit is partly due to higher release of DON (mainly urea) in summer and, probably also to the accumulation of ammonia and nitrate in the pore water (Lerat et al. 1985). $\mathrm{N}_{2}$ loss to the atmosphere might also be enhanced during the summer, since anoxic denitrification can occur in close proximity of nitrification, which needs oxygen (Jenkins \& Kemp 1984).

The observed seasonal variations in the metabolic rates of oysters are in agreement with previous results on other marine bivalves (Bayne 1976 and Bayne \& Scullard 1977 on Mytilus edulis; Srna \& Baggaley 1976 on Crassostrea virginica), being influenced by temperature, body size and physiological state. In the litera- ture, most of the data on oyster excretion result from measurements performed under laboratory conditions with filtered or artificial seawater, on unfed animals or after feeding on cultured phytoplankton diet, followed by some hours starvation to empty the gut (Table 2). In our in situ experiments, we measured high ammonia excretion rates, corresponding to routine excretion of unstressed organisms feeding on a natural diet. Our data suggest in situ stimulated ammonia release and depressed oxygen uptake if compared to laboratory results with Crassostrea gigas (Boucher-Rodoni unpubl.), a discrepancy already reported for Mercenaria mercenaria (Murphy \& Kremer 1985), due to differences in the quantity and/or the quality of the food ingested and in the form of the excreted nitrogen. Since the natural environmental parameters were adhered to in our experiments, we can assume that the measured rates are a good estimation of the actual contribution of oysters to the fluxes in the ecosystem. In agreement with the results of Saijo \& Mitamura (1971), the nitrate release in the enclosures suggest nitrification in the oyster body ( $7 \%$ of total nitrogen excretion), since the processes are known to be negligible in the water column. Srna \& Baggaley (1976) attempted to

Table 2. Comparison of excretion rates of different species of oysters, measured in different experimental conditions

\begin{tabular}{|c|c|c|c|c|c|c|c|}
\hline Source & Species & $\begin{array}{l}\text { Experimental } \\
\text { conditions }\end{array}$ & $\begin{array}{l}\text { Season/ } \\
\text { Temp. }\end{array}$ & $\begin{array}{c}\text { Total fresh } \\
\text { wt (g) }\end{array}$ & $\begin{array}{c}\text { Dry wt (DW) } \\
(g)\end{array}$ & $\begin{array}{c}\mathrm{NH}_{4} \\
\text { excretion } \\
(\mu \mathrm{mol} \mathrm{g}-1 \\
\left.\mathrm{DW} \mathrm{d}{ }^{-1}\right)\end{array}$ & $\% \mathrm{NH}_{4}$ \\
\hline $\begin{array}{l}\text { Hammen et al. } \\
(1966)\end{array}$ & $\begin{array}{l}\text { Crassostrea } \\
\text { virginica }\end{array}$ & $\begin{array}{l}500 \mathrm{ml} \text { filtered SW } \\
6 \text { ind. } \\
24 \mathrm{~h}\end{array}$ & Spring & 100 & - & $1.56-2.19$ & $58-72$ \\
\hline Hammen (1968) & $\begin{array}{l}\text { Crassostrea } \\
\text { virginica }\end{array}$ & $\begin{array}{l}10-400 \mathrm{ml} \mathrm{SW} \\
5 \text { ind. } \\
24 \mathrm{~h}\end{array}$ & Summer & 101 & - & $0.298-0.978$ & 72 \\
\hline $\begin{array}{l}\text { Sina \& Baggaley } \\
(1976)\end{array}$ & $\begin{array}{l}\text { Crassostrea } \\
\text { virginica }\end{array}$ & $\begin{array}{l}15 \mathrm{l} \text { autoclaved SW } \\
10 \text { ind } \\
24 \mathrm{~h} \\
\text { algal diet }+16 \mathrm{~h} \text { fast }\end{array}$ & $20^{\circ} \mathrm{C}$ & $\begin{array}{l}\text { Variable } \\
101\end{array}$ & $\begin{array}{c}0.5-3.0 \\
-\end{array}$ & $\begin{array}{c}0.03-1.2 \\
0.463\end{array}$ & - \\
\hline $\begin{array}{l}\text { Winter et al. } \\
\text { (1984) }\end{array}$ & $\begin{array}{l}\text { Ostrea } \\
\text { chilensis }\end{array}$ & $\begin{array}{l}1-41 \text { SW } \\
3-40 \text { ind. } \\
5 \mathrm{~h} \\
\text { algal diet }\end{array}$ & $12^{\circ} \mathrm{C}$ & Variable & $\begin{array}{l}0.045 \\
0.8-0.9 \\
2.5\end{array}$ & $\begin{array}{c}119 \\
22.97 \\
25.64\end{array}$ & $\begin{array}{l}- \\
- \\
-\end{array}$ \\
\hline $\begin{array}{l}\text { Chin \& Lee } \\
\text { (1979) }\end{array}$ & $\begin{array}{l}\text { Crassostrea } \\
\text { gigas }\end{array}$ & $\begin{array}{l}2-3 \text { l SW } \\
-\end{array}$ & $15^{\circ} \mathrm{C}$ & $52.1 \pm 13.5$ & $1.35 \pm 0.6$ & 105 & - \\
\hline $\begin{array}{l}\text { Robert et al. } \\
(1982)\end{array}$ & $\begin{array}{l}\text { Crassostrea } \\
\text { gigas }\end{array}$ & $\begin{array}{l}30 \text { l filtered SW } \\
10 \text { ind. } \\
5 \mathrm{~h} \\
\text { algal diet }+36 \text { h fast }\end{array}$ & $\begin{array}{l}\text { Summer } \\
17^{\circ} \mathrm{C}\end{array}$ & - & 1.4 & $41-238$ & $10-33$ \\
\hline Present study & $\begin{array}{l}\text { Crassostrea } \\
\text { gigas }\end{array}$ & $\begin{array}{l}40-501 \text { in situ SW } \\
10 \text { ind. } \\
4 \mathrm{~h} \\
\text { natural diet }\end{array}$ & $\begin{array}{l}\text { Annual } \\
\text { cycle } \\
6-17.5^{\circ} \mathrm{C}\end{array}$ & $65 \pm 3.7$ & $1.57 \pm 0.12$ & $6.7-162$ & 54.5 \\
\hline
\end{tabular}


exclude nitrifying bacteria by sterilizing the experimental seawater in an autoclave, but they still observed a measurable rate of nitrate excretion. A direct contribution of nitrates to nitrogen excretion seems improbable, even if it has been suggested for a crustacean by Spaargaren (1985). Bacteria occurring in some part of the digestive tract of the oyster probably enhance natural nitrification processes. Our data show that amino acids constitute a minor proportion of excretion in natural conditions (less than $5 \%$ ), when salinity or starvation stresses are avoided. The proportion of urea released by oysters appears to vary seasonally, in relation with their physiological state. It can rise up to $49 \%$ of total excretion (annual weighted average of $34 \%$ ). Robert et al. (1982) reported even higher values (30 to $80 \%$ of nitrogen release), for the same species grown in oyster ponds.

Seasonal variations in oxygen consumption and nitrogen release by oysters are thus parallel to the variations recorded for the sediment alone. Oysters and undisturbed sediment either respond similarly to the same environmental constraints, or the fluxes from the sediment are very much influenced by an endofauna (macrofauna and meiofauna) whose physiological rates may be similar to those of oysters.

Until recently, the idea prevailed that the contribution of benthic organisms to the recycling of organic matter is low compared to microbial processes (Billen 1978, Harrison 1978). However, many authors have shown that natural densities of macrobenthic organisms (e. g. polychaetes, molluscs, crustaceans) could account for a substantial part of the nutrient fluxes at the interface (Nixon et al. 1980, Henriksen et al. 1983, Dame et al. 1985, Kristensen 1985, Regnault 1986). Aquaculture with bivalves provides large quantities of nitrogen to the water column, and hence contributes to the fluxes at the interface (Nixon et al. 1976, Dame et al. 1984, 1985). Ammonia concentration was highest at the bottom level above oyster beds (Boucher \& Boucher-Rodoni 1985). The potential contribution of $2 \mathrm{~kg} \mathrm{~m}^{-2}$ of oysters (a minimum on oyster beds) to total bottom exchange rates, (e. g. [oyster rate/oyster + sediment rate $] \times 100$ ) ranged from $5 \%$ in April to $47 \%$ in September-October of total bottom respiration and from $10 \%$ in April to $62 \%$ in October of total bottom production of ammonia and DON. During winter, the oysters enhanced the potential nitrate production, while at the same period high water concentration induced high rates of nitrate absorption into the sediment. The time-weighted average of their potential contribution over the 1985 annual cycle (Table 3) reached $36 \%$ of total nitrogen release, and $26 \%$ of total oxygen uptake at the interface of the oyster bed.

However, simply adding metabolic rates of isolated invertebrates from laboratory or field experiments to
Table 3. Time-weighted average of nitrogen and oxygen fluxes (mol m $\mathrm{m}^{-2} \mathrm{yr}^{-1}$ ) and $\mathrm{O}: \mathrm{N}$ ratios resulting from sediment and from $2 \mathrm{~kg} \mathrm{~m}^{-2}$ oysters Crassostrea gigas

\begin{tabular}{|lccc|}
\hline & Sediment & Oysters & $\begin{array}{c}\text { Oysters' } \\
\text { contribution } \\
\text { to total flux (\%) }\end{array}$ \\
\hline $\mathrm{NH}_{4}$ & +1.35 & 0.80 & 37.2 \\
$\mathrm{NH}_{2}$ & +0.47 & 0.07 & 13.0 \\
$\mathrm{Urea}$ & +0.76 & 0.50 & 39.7 \\
$\mathrm{NO}_{3}$ & -0.42 & 0.10 & \\
$\mathrm{~N}-$ release & +2.58 & 1.47 & 36.3 \\
$\mathrm{O}_{2}$ & +45.50 & 16.30 & 26.4 \\
$\mathrm{O}: \mathrm{N}-\mathrm{NH}_{4}$ & +33.70 & 20.70 & \\
$\mathrm{O}: \mathrm{N}-\mathrm{NH}_{4}+\mathrm{DON}$ & 17.6 & 11.30 & \\
\hline
\end{tabular}

total benthic system rates measured in situ, but excluding the animals, does not take into account a multitude of potential interactions between various system components. The results of enclosure experiments with 10 oysters associated with $0.2 \mathrm{~m}^{2}$ sediment demonstrated a seasonal regulation of the fluxes. Compared to the potential contribution, when oysters were lying on the sediment, the actual oxygen consumption and ammonia release were generally depressed (50 to $80 \%$ and 45 to $65 \%$ respectively), except during winter and spring when respiration was stimulated. An enhanced decrease in $\mathrm{NO}_{3}$ absorption of the association, when compared to the sum of sediment and oysters alone, indicates a stimulated nitrification. The presence of a substratum is known to reduce the excretory rate of epibenthic shrimps by decreasing their locomotory activity (Regnault 1986). No such behavioural effect can be assessed for sessile organisms. Either the metabolic rates are constant and the sediment regulates the exchanges by absorbing ammonia and reducing its own oxygen consumption, or else the oysters reduce their metabolic rates when associated with a substratum, e. $g$. the regulatory role of the sediment would then be indirect.

The nitrogen input in benthic ecosystem is both of dissolved and particulate nature. Biodeposition experiments suggest that nitrogen input through the feces $10.27 \mathrm{~mol} \mathrm{~N} \mathrm{~m}^{-2} \mathrm{yr}^{-1}$ assuming a $0.2 \%$ nitrogen content for the same species in the wild; Sormin 1981) is low when compared to potential seston sedimentation (Wafar 1981). Feces and pseudofeces would represent only $15.5 \%$ of the total nitrogen release of oysters in the ecosystem, a low value when compared to the results obtained in other localities by Sornin et al. (1983).

The relative importance of dissolved benthic release of nitrogen was compared to nutrient demand of planktonic net production in the water column above the oyster bed, although the water flows over the beds 
increased the water masses influenced by the bottom fluxes. ${ }^{14} \mathrm{C}$ primary production in the area $\left(300 \mathrm{~g} \mathrm{C} \mathrm{m}^{-2}\right.$ $\mathrm{yr}^{-1}$ ) was recalculated from data of Wafar (1981) for the surface $4 \mathrm{~m}$ (mean water depth above oyster beds) with a mean C:N ratio of 6.8 . Sediment flux of ammonia could satisfy $1.6 \pm 0.4$ (spring) to $3.5 \pm 1$ (autumn) times the daily demand of the water column, and ammonia release by the association of oysters and sediment, respectively $2 \pm 0.5$ to $6.3 \pm 2.6$ times this requirement. Restitution of nitrogen by sediment diffusion processes and excretion of benthic organisms allow a prolongation of both spring and fall planktonic bloom, at periods (June and September-October) when the concentrations are limiting.

Acknowledgements. This research was supported by grant GIS Aquaculture No. 85/2510582 of IFREMER, and carried out at the Station Biologique de Roscoff (L. P. CNRS 4601). We are indebted to $Y$. Craignou, L. Cras and C. Faidy for technical assistance, and to P. Brannelec who provided the facilities on the oyster beds. We thank Drs S. Gerlach and M. Wafar for helpful comments and critical reading of the manuscript.

\section{LITERATURE CITED}

Aminot, A., Kerouel, R. (1982). Dosage automatique de l'urée dans l'eau de mer: une méthode très sensible à la diacétylmonoxime. Can. J. Fish. aquat. Sci. 39: 174-183

Aller, R. C. (1978). Experimental studies of changes produced by deposit feeders on pore water, sediment and overlying water chemistry. Am. J. Sci. 278: 1185-1234

Bayne, B. L. (ed.) (1976). Marine mussels their ecology and physiology. Cambridge Univ. Press, London

Bayne, B. L., Scullard, C. (1977). Rates of nitrogen excretion by species of Mytilus (Bivalvia: Mollusca). J. mar. biol. Ass. U. K. $57: 355-369$

Bernard, F. R. (1974). Annual biodeposition and gross energy budget of mature Pacific oysters Crassostrea gigas. J. Fish. Res. Bd Can. 31: 185-190

Billen, G. (1978). A budget of nitrogen recycling in North Sea sediments off the Belgian coast. Estuar. coast. mar. Sci. 7 : $127-146$

Boucher, G., Boucher-Rodoni, R. (1984). Quantification des rejets azotés biogènes à l'interface des parcs ostréicoles. Rapp. Contrat GIS ANV (Ref. 82/2785, CNEXO/CNRS): $1-45$

Boucher, G., Boucher-Rodoni, R. (1985). Fluctuations des nutriments au cours de la marée sur les parcs ostréicoles de la rivière Penzé (Nord-Finistère). Hydrobiologia 123: $251-261$

Brezonik, P. L. (1977). Denitrification in natural waters. Prog. Wat. Tech. 8: 373-392

Boynton, W. R., Kemp, W. M., Osborne, C. G. (1980). Nutrient fluxes across the sediment-water interface in the turbid zone of a coastal plain estuary. In: Kennedy V. S. (ed.) Estuarine perspectives. Academic Press, New York, p. 93-109

Bulleid, N. L. (1984). Deoxygenation and remineralization above the sediment-water interface; an in situ experimental study. Estuar, coast. Shelf Sci. 19: 15-25

Chin, P., Lee, B. K. (1979). Nitrogen excretion in the bivalve molluscs. Bull. Korean Fish. Soc. 12 (4): 293-296
Dame, R. F., Zingmark, R. G., Haskin, E. (1984). Oyster reefs as processors for estuarine materials. J exp. mar. Biol. Ecol. 83: 239-247

Dame, R. F., Zingmark, R. G., Nelson, D. (1979). Filter feeder coupling between the estuarine water column and benthic subsystems. In: Kennedy, V. S. (ed.) Estuarine perspectives. Academic Press, New York, p. 521-526

Dame, R. F., Wolaver, T. G., Libes, S. M. (1985). The summer uptake and release of nitrogen by an interstitial oyster reef. Neth. J. Sea Res. 19 (3/4): 265-268

Fisher, T R., Carlson, P. R., Barber, R. T (1982). Carbon and nitrogen productivity in three North Carolina estuaries. Estuar. coast. Shelf Sci. 15: 621-644

Galtsoff, P. S. (1964). The american oyster, Crassostrea virginica (Gmelin). Fish. Bull. Fish. Wildl. Serv. U.S. 64: 1-480

Hammen, C. S. (1968). Aminotransferase activities and amino acid excretion of bivalve molluscs and brachiopods. Comp. Biochem. Physiol. 26: $697-705$

Hammen, C. S., Miller, Jr, H. F., Geer, W. H. (1966). Nitrogen excretion of Crassostrea virginica. Comp. Biochem. Physiol. 17: 1199-1200

Harrison, W. G. (1978). Experimental measurement of nitrogen remineralization in coastal waters. Limnol. Oceanogr. 23: $684-694$

Hargrave, B. T (1980). Factors affecting the flux of organic matter to sediments in a marine bay. In: Tenore K., Coull B. (eds.) Marine benthic dynamics. Univ. South Carolina Press, Columbia, p. 243-263

Henriksen, K., Hansen, J. I., Blackburn, T. H. (1981). Rates of nitrification, distribution of nitrifying bacteria and nitrates fluxes in different types of sediment from Danish waters. Mar. Biol. 61: 299-304

Henriksen, K., Rasmussen, M. B., Jensen, A. (1983). Effect of bioturbation on microbial nitrogen transformations in the sediment and fluxes of ammonium and nitrate to the overlying water In: Halberg R. (ed.) Environmental biogeochemistry. Ecui. Buil. (Siocknoim) 35: 193-205

Jenkins, M. C., Kemp, W. M. (1984). The coupling of nitrification and denitrification in two estuarine sediments. Limnol. Oceanogr. 29 (3): 609-619

Kaspar, H. F., Gillespie, P. A., Boyer, I. C., MacKenzie, A. L. (1985). Effects of mussel aquaculture on the nitrogen cycle and benthic communities in Kenepuru Sound, Marlborough Sounds, New Zealand. Mar. Biol. 85: 127-136

Kelly, J. R., Nixon, S. W. (1984). Experimental studies of the effect of organic deposition on the metabolism of a coastal marine bottom community. Mar. Ecol. Prog. Ser. 17: $157-169$

Kemp, W. M., Boynton, W. R. (1979). Nutrient budgets in a coastal plain estuary: sources, sinks and internal dynamics. Am. Soc. Limnol. Oceanogr. Abstracts, 42 Annual Meeting, Stony Brook, New York

Klump, V. J., Martens, C. S. (1983). Benthic nitrogen regeneration. In: Carpenter E. J., Capone D. G. (eds.) Nitrogen in the marine environment. Academic Press, New York, p. $411-457$

Kristensen, E. (1984). Effect of natural concentrations on nutrient exchange between a polychaete burrow in estuarine sediment and the overlying water. J. exp. mar Biol. Ecol. 75: $171-190$

Kristensen, E. (1985). Oxygen and inorganic nitrogen exchange in a Nereis virens (Polychaeta) bioturbated sediment-water system. J. coast. Res. 1 (2): 109-116

Lerat, Y., Boucher, G., LeCorre, P. (1985). Echanges à l'interface eau-sédiment dans un secteur côtier à forte biodéposition (parc ostréicole). Cas de l'ammonium et des nitrates. Cah. Biol. mar. 26 (4): $393-408$ 
Murphy, R. C., Kremer, J. N. (1985). Bivalve contribution to benthic metabolism in a California lagoon. Estuaries 8 (4) $330-341$

Nedwell, D. B. (1982). Exchange of nitrate and the products of bacterial nitrate reduction, between seawater and sediment from a U. K. saltmarsh. Estuar coast. Shelf. Sci. 14: $557-566$

Nixon, S. W. (1981). Remineralization and nutrient cycling in coastal marine ecosystems. In: Neilson B. J., Cronin, L. E. (eds.) Estuaries and nutrients. The Humana Press, Clifton, New Jersey, p. 111-138

Nixon, S. W. Kelly, J. R, Furnas, B. N., Oviatt, C. A., Hale, S. S. (1980). Phosphorus regeneration and the metabolism of coastal marine bottom communities. In: Tenore, K. R. Coull B. C. (eds.) Marine benthic dynamics. Univ. South Carolina Press, Columbia, p. 219-242

Pamatmat, M. M. (1968). Ecology and metabolism of a benthic community on an intertidal sand flat. Int. Revue ges. Hydrobiol. 53: 211-298

Regnault, M. (1986). Production de NH4 par la crevette Crangon crangon dans deux écosystèmes côtiers. Approche expérimentale et étude de l'influence du sédiment sur le taux d'excrétion. J. exp. mar. Biol. Ecol. 100: 113-126

Robert, J. M., Maestrini, S. Y., Héral, M., Zanette, Y. (1982). Production des microalgues des claires ostréicoles en relation avec l'azote organique dissous excrété par les huitres. Oceanol. Acta No. Sp. Proceed. Int. Symp. Coast. Lagoons SCOR/IABO Bordeaux France 8-14 septembre 1981, p. $389-395$

Saijo, Y., Mitamura, O. (1971). Regeneration of nutrients in the waters of a coastal oyster bed. In: Uda, M. (ed.) The ocean world. Jpn. Soc. Promotion Sci., Tokyo, p. 242-248

Smith, K. L. (1973). Respiration of sublittoral community. Ecology 54: $1065-1075$

Solorzano, L. (1969). Determination of ammonia in natural waters by the phenolhypochlorite method. Limnol. Oceanogr. 14: 799-801

Sornin, J. M. (1981). Processus sédimentaires et biodéposition liés à différents modes de conchyliculture (Baie de Cancale, Anse de l'Aiguillon et Bassin de Marennes-Oléron). Thèse 3ème cycle, Univ. Nantes
Sornin, J. M., Feuillet, M., Héral, M., Deslou-Paoli, J. M. (1983). Effet des biodépôts de l'huitre Crassostrea gigas (Thunberg) sur l'accumulation de matières organiques dans les parcs du bassin de Marennes-Oléron. J. mollusc. Stud. (Suppl. 12A): 185-197

Spaargaren, D. H. (1985). The significance of nitrate in the nitrogenous excretion of Carcinus maenas. Neth. J. Sea Res. 19: 119-124

Sma, R. F., Baggaley, A. (1976). Rate of excretion of ammonia by the hard clam Mercenaria mercenaria and the american oyster Crassostrea virginica. Mar Biol. 36: 251-258

Tenore, K. R., Boyer, L. F., Cal, R. M., Corral, J., GarciaFernandez, C., Gonzalez: N., Gonzalez-Gurraran, E., Hanson, R. B., Iglesias, J., Krom, M., Lopez-Jamar, E., McClain, J., Pamatmat, M. M., Perez, A., Rhoads, D. C., de Santiago, G., Tietjen, J., Westrich, J., Windom, H. L. (1982). Coastal upwelling in the Rias Bajas, NW Spain: contrasting the benthic regimes of the Rias de Arosa and de Muros. J. mar. Res. 40: 701-772

Treguer, P., LeCorre, P. (1975). Manuel d'analyse des sels nutritifs dans l'eau de mer (utilisation de l'autoanalyseur Technicon IIR), 2e éd. Univ. Bretagne Occidentale, Brest

Udenfriend, S., Stein, S., Bohlen, P., Dairman, W., Leimgruber, W., Weigele, M. (1972). Fluorescamine: a reagent for assay of amino acids, peptides, proteins and primary amines in the picomole range. Science 178: 871-872

Wafar, M. (1981). Nutrients, primary production, and dissolved and particulate organic matter in well-mixed temperate coastal waters (Bay of Morlaix - Western english Channel). Thèse 3ème cycle, Univ. Pierre et Marie Curie, Paris

Winter, J. E., Acevedo, M. A., Navarro, J. M. (1984). Quempillén estuary, an experimental oyster cultivation station in southern Chile. Energy balance in Ostrea chilensis. Mar Ecol. Prog. Ser. 20: 151-164

Zeitzschel, B. F. (1980). Sediment water interactions in nutrient dynamics. In: Tenore K., Coull B. (eds.) Marine benthic dynamics. Univ. South Carolina Press, Columbia, p. $195-212$ 